\title{
Anomalous formation of the portal vein: a case report
}

\author{
Formação anômala da veia porta: relato de caso
}

\section{Vasavi Rakesh Gorantla, ${ }^{1}$ Bhagath Kumar Potu, ${ }^{1}$ Thejodhar Pulakunta, ${ }^{1}$ Venkata Ramana Vollala, ${ }^{2}$ Pavan Kumar Addala, ${ }^{3}$ Soubhagya Ranjan Nayak ${ }^{4}$}

\begin{abstract}
The knowledge about the formation and relations of the portal vein is important for surgeons and radiologists. The variations in the level of formation and the pattern of formation of portal vein might lead to confusions during radiological and surgical procedures. Here we present a rare variation in the formation of the portal vein as found during the cadaveric dissections. The portal vein was formed by the union of splenic vein, superior mesenteric vein and inferior mesenteric veins. The abnormal termination of left gastric vein into superior mesenteric vein before the formation of portal vein was also seen in the same cadaver. Identification of these variations is useful in managing traumatic rupture of the mesentery.
\end{abstract}

Keywords: Variations, portal vein, obstruction, malrotation.

\section{Introduction}

The portal vein is normally formed by union of the splenic and superior mesenteric veins, around the level of L2, anterior to the inferior vena cava and posterior to the pancreas. It then passes superiorly and runs posterior to the first part of the duodenum. At the porta hepatis it divides into a left and right branch. The portal vein drains blood from all parts of the digestive tract (apart from the lower part of the rectum), the pancreas, spleen and gallbladder. Variant portal architecture has been found in $20-35 \%$ of individuals. ${ }^{1,2}$ Two common variations include: (a) trifurcation of the portal vein, where there is absence of the right trunk proper, such that the right anterior and posterior branches stem from the portal trunk at the same point as the left portal vein; and (b) the right posterior branch coming off the main portal vein rather than from the right portal vein. ${ }^{1,2}$ Individual segmental branches arising away from their usual

\section{Resumo}

O conhecimento sobre a formação e as relações da veia porta é importante para cirurgiões e radiologistas. As variações no nível de formação e o padrão de formação da veia porta podem causar confusões durante procedimentos cirúrgicos e radiológicos. Neste relato, apresentamos uma variação na formação da veia porta encontrada durante as dissecções cadavéricas. A veia porta foi formada pela união da veia esplênica, veia mesentérica superior e veias mesentéricas inferiores. A terminação anormal da veia gástrica esquerda na veia mesentérica superior antes da formação da veia porta também foi observada no mesmo cadáver. A identificação dessas variações é útil para tratar a ruptura traumática do mesentério.

Palavras-chave: Variações, veia porta, obstrução, má-rotação.

point of origin is another commonly reported variation. ${ }^{1}$

Knowledge of these variations in portal anatomy is important in the preoperative work-up prior to liver transplantation or resection, as knowledge of the individual patient's vascular anatomy helps to minimize the likelihood of postoperative liver ischemia. ${ }^{1}$ There is also a potential benefit for the interventional radiologist in knowing vascular detail prior to catheter-based interventions. ${ }^{1}$ There are several reports on variations on the termination of portal vein in the porta hepatis, but studies on formation of portal vein and its anomalous course are lacking.

\section{Case report}

During routine dissections for undergraduate medical students in Department of Anatomy, KMC,

1. Department of Anatomy, Centre for Basic Sciences, Kasturba Medical College, Manipal, Karnataka, India.

2. Department of Anatomy, Melaka Manipal Medical College (Manipal Campus), Manipal, Karnataka, India.

3. Department of Surgery, Kasturba Medical College, Manipal, Karnataka, India.

4. Department of Anatomy, Centre for Basic Sciences, Kasturba Medical College, Mangalore, Karnataka, India.

Manuscript received June 18, 2007, accepted on August 20, 2007.

J Vasc Bras. 2007;6(4):399-401.

Copyright $\odot 2007$ by Sociedade Brasileira de Angiologia e de Cirurgia Vascular 


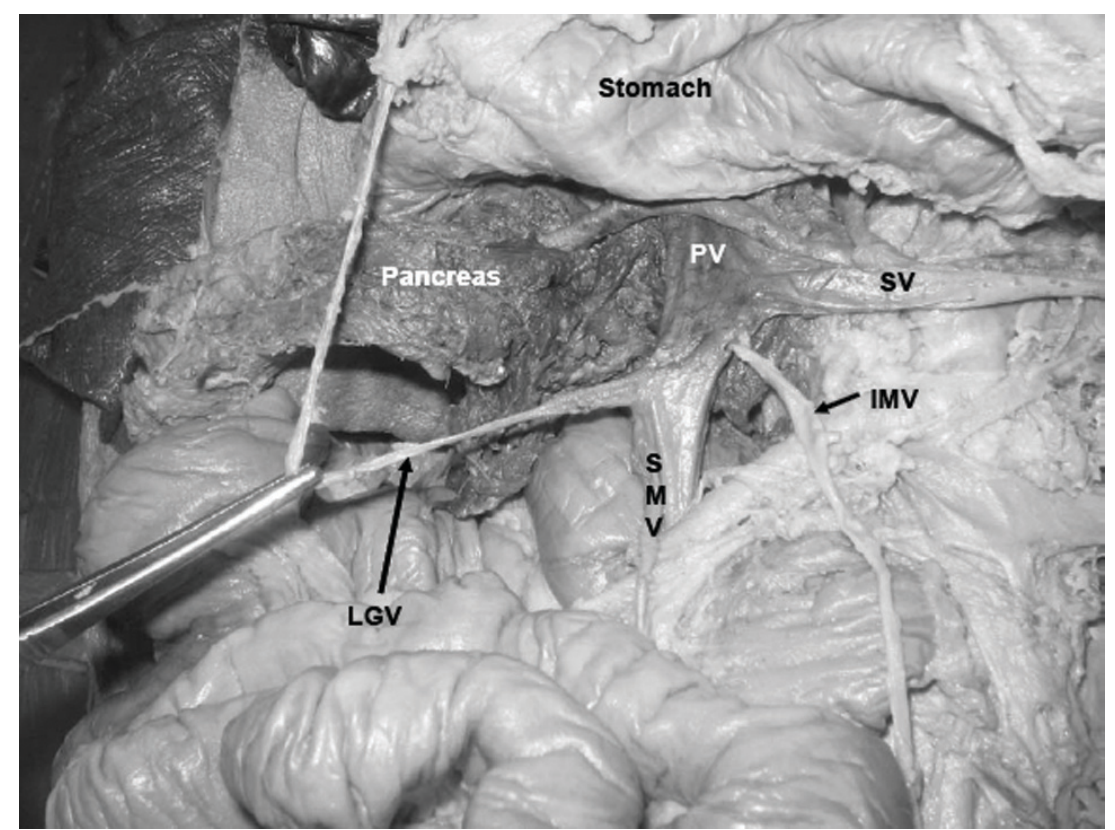

$\mathrm{IMV}=$ inferior mesenteric vein; $\mathrm{LGV}=$ left gastric vein; $\mathrm{PV}=$ portal vein; $\mathrm{SMV}=$ superior mesenteric vein; $\mathrm{SV}=$ splenic vein.

Figure 1 - Dissection of the abdomen showing formation of the portal vein by three veins

Manipal, a male cadaver about 54 years showed a variation in the formation of the portal vein. The formative tributaries were superior mesenteric vein, splenic vein and inferior mesenteric vein. Moreover, the left gastric vein was seen terminating into superior mesenteric vein before the formation of portal vein (Figure 1). All the formative tributaries were carefully dissected and photographs were taken.

\section{Discussion}

The portal vein is rarely variable. Identifying deviations from normal portal architecture is important in the work-up for surgery such as liver transplantation, and prior to interventional procedures such as stent placement or embolization. There are several reports on variations on the termination of portal vein in the porta hepatis, but studies on formation of portal vein and its anomalous course are lacking. Bergman et al. have reported the absence of portal vein and opening of superior mesenteric and splenic veins into the renal vein. ${ }^{3}$ Jin Shan et al. have reported doubling of the portal vein and its clinical implications. ${ }^{4}$ A preduodenal portal vein is a rare congenital anomaly and has been reported a few times. ${ }^{5-7}$ The main clinical significance of a preduodenal portal vein is its association with intestinal obstruction. This can be due to extrinsic compression of the duodenum, or associated intestinal malformations. ${ }^{8}$ Up to $80 \%$ of the obstructions are due to intrinsic lesions of the duodenum or malrotation. ${ }^{9}$ Two-thirds of children with a preduodenal portal vein present in the first week of life. ${ }^{9}$ Other associations include biliary atresia, annular pancreas, situs inversus, preduodenal common bile duct and cardiovascular malformations. ${ }^{8,9}$ Inoue et al. have reported a prepancreatic postduodenal portal vein. ${ }^{10}$

In the embryo, the paired vitelline veins transport blood from the yolk sac to the sinus venosus. During the fourth to fifth weeks of embryonic life, three anastomoses form between the vitelline veins, ${ }^{11}$ these are the cranial-ventral, dorsal and caudal-ventral anastomoses, and are named according to their anatomical 
position and relationship to the primitive foregut that will become the duodenum. From the formation of these anastomoses to the third month of development, there is selective involution of the venous network that eventually produces the portal vein. It has been proposed that aberrations in this process of involution can result in anatomical variations within the portal venous system. ${ }^{12}$

In conclusion, the knowledge of variations in the formation and course of the portal vein is very useful for surgeons performing surgeries of pancreas and duodenum. It is also useful in managing the traumatic rupture of the mesentery. Since there are not many studies on variation in the formation of the portal vein, this study might contribute useful data to the literature regarding the same.

\section{References}

1. Covey AM, Brody LA, Getrajdman GI, Sofocleous CT, Brown KT. Incidence, patterns, and clinical relevance of variant portal vein anatomy. AJR Am J Roentgenol. 2004;183:1055-64.

2. Atri M, Bret PM, Fraser-Hill MA. Intrahepatic portal venous variations: prevalence with ultrasound. Radiology. 1992;184:157-8.

3. Bergman RA, Thompson SA, Afifi AK, Saadeh FA. Compendium of human anatomic variations. Baltimore: Urban \& Schwarzenberg; 1988. p. 70.

4. Esscher T. Preduodenal portal vein--a cause of intestinal obstruction? J Pediatr Surg. 1980;15:609-12.
5. Zhang JS, Wang YP, Wang MQ, et al. Diagnosis of an accessory portal vein and its clinical implications for portosystemic shunts. Cardiovasc Intervent Radiol. 1996;19:239-41.

6. Stevens JC, Morton D, McElwee R, Hamit HF. Preduodenal portal vein: Two cases with differing presentation. Arch Surg. 1978;113:311-3.

7. Yi SQ, Tanaka S, Tanaka A, Shimokawa T, Ru F, Nakatani $\mathrm{T}$. An extremely rare inversion of the preduodenal portal vein and common bile duct associated with multiple malformations. Report of an adult cadaver case with a brief review of the literature. Anat Embryol (Berl). 2004;208:87-96.

8. Choi SO, Park WH. Preduodenal portal vein: a cause of prenatally diagnosed duodenal obstruction. J Pediatr Surg. 1995;30:1521-2.

9. Fernandes ET, Burton EM, Hixson SD, Hollabaugh RS. Preduodenal portal vein: surgery and radiographic appearance. J Pediatr Surg. 1990;25:1270-2.

10. Inoue M, Taenaka N, Nishimura S, et al. Prepancreatic postduodenal portal vein: report of a case. Surg Today. 2003;33:956-9.

11. Sadler T. Cardiovascular system. In: Sadler TW, editor. Langman's medical embryology. 8th ed. Philadelphia: Lippincott Williams \& Wilkins; 2000. p. 246-8.

12. Niwa T, Aida N, Tachibana K. Congenital absence of the portal vein: clinical and radiological findings. J Comput Assist Tomogr. 2002;26:681-6.
Correspondence:
Bhagath Kumar Potu
Department of Anatomy
Centre for Basic Sciences, Kasturba Medical College
576104 - Manipal, Karnataka - India
Tel.: (91) 820-2922327
E-mail: potu_kumar2000@yahoo.co.in 